\title{
Investigating Knowledge, Attitude and Health Care Waste Management by Health Workers in a Nigerian Tertiary Health Institution
}

\author{
E. Ezeoke Uchechukwu ${ }^{1}$, I. Omotowo Babatunde ${ }^{1} \&$ C. Ndu Anne ${ }^{1}$ \\ ${ }^{1}$ Department Community Medicine, College of Medicine, University of Nigeria, Enugu Campus/University of \\ Nigeria Teaching Hospital, Ituku-Ozalla, Enugu, Nigeria \\ Correspondence: I. Omotowo Babatunde, Department Community Medicine, College of Medicine, University of \\ Nigeria, Enugu Campus/University of Nigeria Teaching Hospital, Ituku-Ozalla, Enugu, Nigeria. E-mail: \\ babatunde.omotowo@unn.edu.ng
}

Received: January 3, 2017 Accepted: February 22, 2017 Online Published: March 7, 2017

doi:10.5539/gjhs.v9n4p222 URL: https://doi.org/10.5539/gjhs.v9n4p222

\begin{abstract}
Introduction: Inadequate knowledge and practice of health care waste management by health workers may have serious health consequences and a significant impact on the environment.

Objective: The purpose of the study was to ascertain the knowledge, attitude and practice of hospital waste management among health workers in Enugu.

Methods: A cross sectional descriptive survey was carried out among 115 health workers at the University of Nigeria Teaching Hospital Enugu. Data were collected using self-administered questionnaire, and was analysed using SPSS version 21. Statistical significance of association between variables was assessed using Chi-square test at $\mathrm{p}<0.05$. Ethical clearance was obtained from the Research Ethics Committee of UNTH
\end{abstract}

Results: All 115 respondents returned the completed questionnaires. Sixty $(52.2 \%)$ were females and fifty five $(47.8 \%)$ were males. The mean age of respondents was $31.7 \pm 11.8$ years. Ninety three $(80.9 \%)$ had heard of hospital waste management, $95(83 \%)$ were aware that hospital waste is classified into hazardous and non-hazardous waste. Ninety nine $(86.1 \%)$ were aware of waste segregation, only $25(21.7 \%)$ dispose medical waste in specified color coded container always. Majority 90 (78.3\%) use latex gloves when handling waste.

Conclusion: Most of the respondents knew what health care waste management means (HCWM), but very few practiced appropriate health care waste management. Health education and training is recommended for the health care workers periodically and regularly.

Keywords: perception, attitude, practice, health care, Waste management

\section{Introduction}

Health care waste (HCW) includes all the waste generated by healthcare establishments, research facilities and laboratories (Pruss, Groult, \& Rushbrook., 1999). Hospital waste is any solid or liquid waste from the hospital which may present a threat of infection to humans. WHO assessment in 22 developing countries in 2002, revealed that $18-64 \%$ of health facilities do not use proper disposal methods (Patwary et al., 2009; Jean et al., 2014).

HCW can be categorized into hazardous and non hazardous waste (Sahr, Abeer, \& Nervana, 2012; Azage, Gebrehiwot, \& Molla, 2013) or communal and biomedical waste (Vikas \& Ramesh., 2015). The hazardous health care waste carries a higher potential for infection and injury than any other type of waste. Inadequate knowledge of handling of healthcare waste may have serious health consequences and a significant impact on the environment as well (Marthur, Dwivedi, Hassan, \& Misra, 2011; Nkonge, Mayabi, Kithinji, \& Kgzi, 2012). Many studies have shown that wrong handling and disposal of health care waste poses higher risk of diseases such as hepatitis and HIV/AIDS to health workers, and people who are near health facilities (Ujuwal, 2013; Stephen \& Elijah, 2011). Globally, WHO estimated about 8 to 16 million new cases of Hepatitis B, 2.5 to 4.9 million of Hepatitis C, and 100,000 to 190,000 cases of HIV are due to unsafe injections and poor health care waste management (Stephen $\&$ Elijah, 2011; World Health Organization, 2004).

The hospital waste management has diverse ramifications as it not only affects the health of patients but also of 
health care workers (doctors, nurses, sanitary staff etc) and general public (Marthur et al., 2011; Shinee, Gombajav, Nishimura, \& Hamajima.,2008).

In Nigeria, HCW falls under the category of infectious waste. Within this category are culture and stock of infectious agents, pathological waste, waste from surgery or autopsy that were in contact with infectious agents, sharps (hypodermic needles, syringes, scalpel blades) waste from human blood products and laboratory waste (Bassey, Coker, \& Aluji., 2006; Njiru, Mutai, \& Gikunju., 2013 ).

The management of hospital waste is undertaken by health care facilities that generate the waste. Service providers collect the wastes from the health care facilities and transport them to waste treatment facilities that process the waste to make it safe for final disposal (Ujuwal, 2013). Steps for HCW management include creating awareness, defining policy, setting up a strategy as well as waste management plans (Ujuwal, 2013). Adequate knowledge of the health hazards of hospital waste, proper techniques and methods of handling the waste and practice of safety measures can equip the HCW for the safe disposal of hazardous hospital waste and protect the community from various adverse effects of the hazardous wastes (Marthur et al., 2011).

Nigeria at present does not have a co-ordinated health care waste management system, especially in the area of segregation, collection, storage, treatment and disposal. The level of awareness among healthcare workers regarding health care waste has not been adequately documented in Nigeria (Abubakar, 2013; Stephen \& Elijah, 2011). Many health facilities in Nigeria do not have a specific policy for management of hospital waste (Olufunsho, Aishat, \& Azuka, 2016)

The study therefore aims at investigating the knowledge, and health care waste management among health workers in Enugu State, Nigeria.

\section{Materials and Methods}

\subsection{Study Population}

Health workers in University of Nigeria Teaching Hospital (UNTH) Ituku Ozalla Enugu, southern, Nigeria was the target population. UNTH is a tertiary hospital in Nigeria and serves mostly people in South east and South south states of the country. It has over 400 beds, 25 wards, 28 clinics, 741 doctors, 775 nurses, 121 Pharmacists, 230 laboratory scientists and laboratory technicians, and 54 physiotherapists (Casmir \& Obi, 2013).

\subsection{Study Design and Sampling Technique}

This cross sectional study was carried out to ascertain the knowledge, attitude and health care waste management among health care workers in a tertiary hospital. A total of 115 health workers were selected through a multi-stage sampling method. The first stage of sampling was the random selection of the health facility from a list of tertiary public health facilities in Enugu. Health workers were subsequently stratified according to their different duty posts or units (clinics, wards, theatres, mortuary, and delivery rooms). Proportional sampling method was used to select health care workers from different units/wards. Health care workers that have worked for more than six months in the hospital were included in the study.

\subsection{Data Collection}

Semi-structured, self administered questionnaires were distributed to all selected health workers. All 115 questionnaires were retrieved. The questionnaire included socio-demographic characteristics, knowledge on HCW, attitude, availability of $\mathrm{HCW}$ management plan, presence of waste management team, and also type of waste treatment and disposal methods used in the facility.

\subsection{Data Analysis}

Data was entered and analysed using Statistical Package for Social Science (SPSS) version 21.

\subsection{Ethical Clearance}

Informed written consent was obtained from the participants, while ethical clearance was obtained from the Health Research Ethics Committee of the UNTH, Ituku Ozalla.

\subsection{Limitations}

Representation of all units was a challenge

Getting health care workers at their duty post was also a challenge 


\section{Results}

All 115 questionnaires were retrieved. Males were 60(52\%), and females 55(48\%), while the age range was $20-$ 59 years, with a mean of $31.70 \pm 11.7$ years. Forty Seven $(40.9 \%)$ were single, $65(56.4 \%)$ were married (Table 1).

Table 1. Socio-Demographic Characteristics

\begin{tabular}{|c|c|c|}
\hline Age in years & Frequency & Percentage \\
\hline $20-24$ & 10 & $8.7 \%$ \\
\hline $25-29$ & 32 & 27.8 \\
\hline $30-34$ & 19 & 16.5 \\
\hline $35-39$ & 17 & 14.8 \\
\hline $40-44$ & 16 & 13.9 \\
\hline $45-49$ & 4 & 3.5 \\
\hline $50-54$ & 7 & 6.1 \\
\hline $55-59$ & 3 & 2.6 \\
\hline Non response & 3 & 6.1 \\
\hline Total & 115 & 100.0 \\
\hline \multicolumn{3}{|l|}{ Mean age $-31.7 \pm 11.7$} \\
\hline \multicolumn{3}{|l|}{ Marital Status } \\
\hline Single & 47 & 40.9 \\
\hline Married & 65 & 56.4 \\
\hline Separated & 1 & 0.9 \\
\hline Divorced & 1 & 0.9 \\
\hline Non response & 1 & 0.9 \\
\hline Total & 115 & 100 \\
\hline \multicolumn{3}{|l|}{ Education Status } \\
\hline Non formal education & 1 & 0.9 \\
\hline Primary & 13 & 11.3 \\
\hline Secondary & 19 & 16.5 \\
\hline Tertiary & 82 & 71.3 \\
\hline Total & 115 & 100 \\
\hline \multicolumn{3}{|l|}{ Sex } \\
\hline Female & 60 & 52.2 \\
\hline Male & 55 & 47.8 \\
\hline Total & 115 & 100 \\
\hline
\end{tabular}


Table 2 shows 93 (80.9\%) had heard of HWM, 20(17.4\%) had not, while 2(1.7\%) did not respond.

Table 2. Proportion of respondents who have heard of hospital waste management (HWM)

\begin{tabular}{lll}
\hline Variables & Frequency & Percentage \\
\hline Ever heard of HWM & 93 & 80.9 \\
Never heard of HWM & 20 & 17.4 \\
No response & 2 & 1.7 \\
Total & 115 & 100 \\
\hline
\end{tabular}

Sixty six (57.4\%) of the respondents were aware that the facility had a waste management plan, while $37(32 \%)$ did not know (Table3).

Table 3. Awareness of a waste management plan in the Health Facility

\begin{tabular}{lll}
\hline Variables & Frequency & Percentage \\
\hline $\begin{array}{l}\text { Affirmed availability of waste management plan in the } \\
\text { hospital }\end{array}$ & 66 & 57.4 \\
$\begin{array}{l}\text { Not aware of any waste management plan in the } \\
\text { hospital }\end{array}$ & 7 & 6.1 \\
No response & 5 & 4.3 \\
Total & 115 & 100 \\
\hline
\end{tabular}

Table 4 shows that Sixty six (59\%) of the respondents were aware of the presence of a waste management team, $33(29 \%)$ were not aware, while 7(6\%) did not respond.

Table 4. Awareness of waste management team in the hospital

\begin{tabular}{lll}
\hline Variables & Frequency & Percentage \\
\hline $\begin{array}{l}\text { Affirmed the presence of waste management team in the } \\
\text { hospital }\end{array}$ & 68 & 59 \\
Not aware of waste management team in the hospital. & 33 & 29 \\
Certain that there is no waste management plan & 7 & 6 \\
No respons e & 7 & 6 \\
Total & 115 & 100.0 \\
\hline
\end{tabular}


Forty nine (42.6\%) knew legislation is applicable to HWM, while $62(53.9 \%)$ were not aware of any legislation (Table 5).

Table 5. Awareness of legislation applicable to health care waste

\begin{tabular}{lll}
\hline Variables & Frequency & Percentage \\
\hline Not aware of legislation applicable to HCWM & 62 & 53.9 \\
Aware of legislation applicable to HCWM & 49 & 42.6 \\
No response & 4 & 3.5 \\
Total & 115 & 100.0 \\
\hline
\end{tabular}

Sixty three $(54.8 \%)$ of the workers were aware of the use of color coded containers for waste disposal while 47(40.9\%) did not know (Table 6).

Table 6. Awareness of use of color codes for different waste containers

\begin{tabular}{lll}
\hline Awareness of use of colour codes & Frequency & Percentage \\
For different containers & & 54.8 \\
\hline Aware of use of colour codes for different containers & 63 & 40.9 \\
Not aware of use of colour codes for different containers & 47 & 4.3 \\
No response & 5 & 100.0 \\
Total & 115 & \\
\hline
\end{tabular}

Table 7 shows the type of treatment and disposal methods known by the participants which include: burning in pits 79 (68.9\%), incineration 58 (50.4\%), chemical disinfection 57 (49.6\%), burying 53 (46.1\%), recycling $50(43.5 \%)$, sanitary landfill 46 (40\%), and composting 35 (30.4\%).

Table 7. Types of Treatment and Disposal Methods knew by the Participants

\begin{tabular}{lll}
\hline Disposal methods & Frequency & Percentage \\
\hline Burnings in pits & 79 & 68.9 \\
Incineration & 58 & 50.4 \\
Chemical disinfection & 57 & 49.6 \\
Burying & 53 & 46.1 \\
Recycling & 50 & 43.5 \\
Sanitary landfill & 46 & 40.0 \\
Composting & 35 & 30.4 \\
Total & 115 & 100.0 \\
\hline
\end{tabular}


One hundred and nine $(94.8 \%)$ of the participants believed that poor waste management can lead to transmission of diseases (Table 8).

Table 8. Awareness that poor hospital waste management can lead to transmission of disease

\begin{tabular}{lll}
\hline $\begin{array}{l}\text { Are you aware that poor waste } \\
\text { Management can lead to disease Transmission }\end{array}$ & Frequency & \\
\hline Yes & 109 & 94.8 \\
No & 1 & 0.9 \\
No response & 5 & 4.3 \\
Total & 115 & 100.0 \\
\hline
\end{tabular}

Table 9 shows 25 (21\%) of the participants always dispose waste in specified colour coded containers, 43 (37.4\%) sometimes, $42(36.5 \%)$ never, while 5 (4.3\%) did not respond.

Table 9. Participants that dispose waste in specified colour containers

\begin{tabular}{llll}
\hline $\begin{array}{l}\text { Do you dispose waste in specified colour coded } \\
\text { containers }\end{array}$ & Frequency & Percentage \\
\hline Always & 25 & 21. \\
Sometimes & 43 & 37.4 \\
Never & 42 & 36.5 \\
No response & 5 & 4.4 \\
Total & 115 & 100.0 \\
\hline
\end{tabular}

Forty two (36.5\%) of the respondents always dispose sharps in sharps specific proof containers, 50 (43.5\%) sometimes, while 18 (15.7\%) never (Table 10).

Table 10. Participants who dispose sharps in sharps specific container

\begin{tabular}{lll}
\hline $\begin{array}{l}\text { Do you Dispose sharps in sharps specific puncture proof } \\
\text { containers? }\end{array}$ & Frequency & Percentage \\
\hline Always & 42 & 36.5 \\
Sometimes & 50 & 43.5 \\
Never & 18 & 15.7 \\
No response & 5 & 4.3 \\
Total & 115 & 100.0 \\
\hline
\end{tabular}


Table 11 shows that ninety (78.3\%) of the respondents always use suitable latex gloves when handling wastes, 20 (17.4\%) sometimes, while no participant reported never using gloves.

Table 11. Participants who use suitable latex gloves when handling wastes

\begin{tabular}{lll}
\hline Do you use suitable latex gloves when handling wastes & Frequency & Percentage \\
\hline Always & 90 & 78.3 \\
Sometimes & 20 & 17.4 \\
Never & 0 & 0.0 \\
No response & 5 & 4.3 \\
Total & 115 & 100.0 \\
\hline
\end{tabular}

Twenty six (22.6\%) of the health workers had received training on HWM, 86(74.8\%) reported they had never received training, While 3(2.6\%) did not respond (Table 12).

Table 12. Participants who had training on Hospital waste Management

\begin{tabular}{lll}
\hline Have you undergone any training on hospital waste management & Frequency & Percentage \\
\hline No & 86 & 74.8 \\
Yes & 26 & 22.6 \\
No response & 3 & 2.6 \\
Total & 115 & 100.0 \\
\hline
\end{tabular}

Table 13 shows opinions of respondents on disposal of hospital waste. 104 (90.4\%) agreed that hospital waste should be disposed properly.

Table 13. Participants opinion on Disposal of hospital waste

\begin{tabular}{lll}
\hline Should hospital waste be properly Disposed off & Frequency & Percentage \\
\hline Yes & 104 & 90.4 \\
No & 7 & 6.1 \\
No Response & 4 & 3.5 \\
Total & 115 & 100.0 \\
\hline
\end{tabular}




\section{Discussion}

Healthcare waste can cause serious harm if not managed properly. Ascertaining the knowledge and hospital waste management (HWM) by health workers themselves will go a long way towards curbing the danger associated with HWM. Our study revealed significant problems with hospital waste management at the tertiary health facility. From this study, $93(80.9 \%)$ of health care workers knew about HWM. This is commendable, but differs from the findings in a study on the knowledge of HWM among senior staff nurses working in a selected medical college hospital of Bangladesh, and also in the study done in Kenyatta national hospital where knowledge about hospital waste and its management among staff was poor (Mohammed \& Rashedul., 2014). Sixty six (57.4\%) of the respondents are aware of presence of a waste management plan in the hospital, 68(59\%) are aware of the presence of a waste management team and 49(42.6\%) are aware of legislation applicable to HWH in the institution. Above results are encouraging but the awareness on legislation was rather poor. The poor knowledge on legislation is comparable to a study in Uganda where 6 out of 8 staff interviewed had no knowledge of document on policies and guidelines. The findings in this study is also comparable to the findings in a study in Dhaka City Bangladesh where it was revealed that lack of appropriate policy and laws were responsible for improper management of medical wastes in Dhaka City (Manzuru, Ahmed, Rahman, \& Kanti., 2014). The awareness on the presence of HWM team and plan from our study differs from a study in Uganda where all the staff interviewed reported that the infection control committee doubled as the waste management committee, they did not receive any specific appointment, written down duties or roles as members of the HWM Committee (Muhwezi, Kaweesa, Kiberu, \& Eiyoku, 2014).

Majority of the healthcare workers $109(94.8 \%)$ were aware that improperly managed waste can lead to transmission of disease. This knowledge is commendable as it can assist the workers in their efforts in medical waste management. This finding agrees with a study done at a hospital in Johannesburg, South Africa where most of the health workers $(98.5 \%)$ knew that improper management of health care waste could lead to transmission of infections among hospital workers and patients (Okale \& Basu, 2009). Eighty six (74.8\%) of health care workers in our study were aware that hospital waste can be divided into hazardous and non-hazardous wastes. This agrees with a study done at University of Part Harcourt Teaching Hospital (UPTH) which showed a high level of awareness among health workers of the different wastes and their hazardous nature (Odigie \& Siminialyi, 2009). This finding in our study is encouraging as it will influence the staff in the way they handle waste. Majority of the respondents $99(86.1 \%)$ were aware of waste segregation, many $63(54.8 \%)$ were aware of colour coding for different categories of medical waste. These findings are comparable to a study in four hospitals in Lagos where health care workers of 3 of the hospitals gave high priority to segregation of infectious wastes (Longe \& Williams, 2006). The finding in this study differs from that conducted in Northern Jordan where segregation was not practiced (Toyobo, Raba, \& Oyeniyi, 2012).

In our study most of the health care workers had a positive attitude towards HWM. One hundred and four (90.4\%) agreed that health care wastes should be disposed off properly in the hospital. This positive attitude could be as a result of high knowledge of the health hazards associated with hospital waste. It is comparable to a study at UPTH where majority of the respondents showed favourable attitudes towards the importance of guidelines on medical waste management and training in, and use of personal protective equipment (Odigie \& Siminialyi, 2009).

In assessing their practice, only 25(21.7\%) of the health care workers used the color coded containers always. This is rather poor and does not agree with studies done at both Lagos and Johannesburg, South Africa (Okale \& Basu, 2009; Longe \& Williams, 2006). In Lagos, a study in 3 hospitals noted that high priority were given to waste segregation using color coded containers, while in South Africa $96 \%$ of the correspondents used the bins appropriately (Okale \& Basu, 2009; Longe \& Williams, 2006).

Most of the workers in our study use sharps specific puncture proof containers, but only a small proportion 42 $(36.5 \%)$ reported using them always. This practice was poor and could be due to lack of HCW training on HWM or lack of safety boxes as was reported in a study in Lagos (Longe \& Williams, 2006).

There was good practice on the use of latex gloves when handling infectious wastes. All the 110(95.7\%) workers who answered the question used gloves. However 90(78.3\%) of them used gloves always, while 20(17.4\%) used gloves sometimes. The use of gloves by the workers in this study agrees with the studies done in Uganda where all the staff were provided with gloves, and South Africa where $95 \%$ of the respondents used gloves always (Okale \& Basu, 2009).

The most common method of waste disposal practiced by the health care workers in our study was burning in pits. 
This finding is comparable to a study done in Lagos where burning of hospital waste was found to be a common practice (Longe \& Williams, 2006). It however differed from another study done in seven hospitals in Lagos where all the hospitals employ the services of Lagos Waste Management Authority (LAWMA) for final waste disposal and treatment except one hospital that offered on-site treatment of waste with incinerator (Olufunsho et al., 2016).

The result of this study does not agree with studies done at the University College Hospital (UCH) Ibadan, and Obafemi Awolowo University Teaching Hospital (OAUTH) Ile-Ife where burying was commonest method of waste disposal (Toyobo et al.,2012). The finding in our study also differs from a study conducted in 21 hospitals in Northern Jordan in which the most frequently used method for solid medical waste was incineration (Fayez, Hani, \& Atallah, 2007).

Eight six (74.8\%) of the workers had not undergone any training, while 26(22.6\%) had received some training on HWM. This poor level of training could account for some of the poor practices witnessed in this study. This finding agrees with a study conducted at Dhaka City which reported that nurses, laboratory clinicians had no training on the handling and the disposal of medical waste (Akter et al., 1999). Our study also agrees with a study in Uganda which reported that none of the staff interviewed received comprehensive training on the waste management (Muhwezi et al., 2014).

\section{Conclusion}

The findings in our study is important for the management of healthcare waste in Nigeria and other developing countries. We have examined the knowledge, and management of health care waste among health workers. The study revealed that the workers had adequate knowledge but practice was poor. This poor practice could have been due to little or no health care waste management training.

Our study also revealed that few workers were aware of a waste management team, plan and legislation in the hospital.

Based on the above findings we make the following recommendations

- Regular and periodic training of workers on HWM should be carried out in the establishment to improve on their knowledge and skills in waste management.

- Policies, legislations and guidelines on HWM should be put in place and awareness created on these documents for the workers.

- Creation of a waste management team and duties of each member clearly defined.

\section{Acknowledgements}

We appreciate all the health workers that participated in this study for providing the essential information.

\section{Competing Interest Satement}

The authors declare there is no conflict of interests concerning the publication of this paper. The study was funded by the authors.

\section{References}

Fayez, A., Hani, A. Q., \& Atallah, R. (2007). Site investigation on Medical Waste Management practices in Northern Jordan. Waste Management, 28, 450-458.

Abubakar, M. (2013). FEC Okays New policy on Waste Management. The Guardian Nigeria.Retrieved from $\mathrm{http} / /$ :www.ngrguardiannews.com International news/11p27-fec-okays-new policy-on waste management. 2013.

Akter, N., Chowdhury, M. R., \& KGzi, N. M. (1999). Hospital Waste Disposal in Bangladesh with special reference to Dhaka City and its Environmental evaluation. Special publication: 87-90.

Azage, M., Gebrehiwot, H., \& Molla, M. (2013). Healthcare waste management practices among healthcare workers in health facilities of Gondar town, Northwest Ethiopia. Health Science Journal, 7(3), 315-22

Bassey, B. E., Coker, N. B., \& Aluji, H. A. S. (2013). Characterization and Management of Solid medical wastes in the Federal Capital Terriotry, Abuja, Nigeria. African Health Sciences, 6(1), 58-63.

Casmir, O., \& Obi, F. (2013). Unpublished data from establishment/records dept of University of Nigeria Teaching 


\section{Hospital Enugu.}

Jean, G. T. D. et al. (2014). Health care waste managemengt: a multi speed development in the sub-Sahara Africa region. The Pan African Medical Journal, 17, 305. https://doi.org/10.11604/pamj.2014.17.305.3965

Longe, E. O., \& Williams, A. (2006). A preliminary study of medical Waste Management in Lagos Metropolis, Nigeria. Iran J. Environ Health sci.Eng, 3(2), 133-139.

Manzuru, H. M., Ahmed, S. A., Rahman, K. A., \& Kanti, T. (2008). Pattern of Medical Waste Management existing scenario in Dhaka city, Bangladesh. BMC Public Health; 8: 36. Marthur V, Dwivedi S, Hassan MA and Misra RP. knowledge, Attitude and Practices among health care personnel: A cross sectional study. Indian Journal of Community Medicine, 36(2), 143-145.

Mohammed, N. U., Rashedul, U. I., \& Yesunn, K. (2014). Health care waste management. Journal of Wastes Management, 2, 10-573069. http:iidx.dio.org/10.1155/2014/573069

Muhwezi, L., Kaweesa, P., Kiberu, F., \& Eiyoku, L. E. (2014). Health Care Waste Management of Uganda - A Case study of Soroto Regional Referral Hospital. Int. Journal of Waste Mangement and Technology, 2(2), 1-2.

Njiru, M. W., Mutai, C., \& Gikunju, J. (2013). Awareness and practice on biomedical waste management among healthcare personnel in Kenyatta national hospital. East Afr Med J, 90(2), 52-58.

Nkonge, N. A., Mayabi, O. A., Kithinji, J., \& Magambo, J. A. (2012). Knowledge, attitude, and practice of health care waste management and associated health risks in the two teaching and referral hospitals in Kenya. $J$ Community Health, 37(6), 1172-7. https://doi.org/10.1007/s10900-012-9580-x

Odigie, J. O., \& Siminialyi, I. M. (2009). Medical Waste Management at University of Port Harcourt Teaching Hospital, Port Harcourt Teaching Hospital, Part Harcourt. Medical Journal, 4(1), 34-37.

Okale, T. R., \& Basu, D. S. (2009). Healthcare waste management on an academic hospital: knowledge and practices of doctors and nurses. South Affrican Medical Journal, 99(6). Retrieved from http//www.scielo.org.za/scielo.php?pid=50256.

Olufunsho, A., Aishat, A. A., \& Azuka, C. O. (2016). Assessment of medical waste management in seven hospitals in Lagos, Nigeria. BMC Public Health, 16, 269. https://doi.org/10.1186/s12889-016-2916-1

Patwary, M. A., O'Hare, W. T., Street, G. et al. (2009). Quantitative assessment of medical waste generation in the capital city of Bangladesh. Waste management, 25(8), 2392-97.

Pruss, A., Groult, G., \& Rushbrook, K. (1990. Health care wastes definition and classification. Safe Management of waste from Healthcare Activities, 2.

Sahr, H. E., Abeer, M. Z., \& Nervana, A. G. (2012). Interaction programme for Nurses about healthcare Waste Management Research. Journal of Medicine and Medical Sciences, 7(1), 25-27

Shinee, E., Gombajav, E., Nishimura, A., \& Hamajima, N. (2008). Health waste management in the capital city of Mongolia. Waste Management, 28, 435-44. https://doi.org/10.1016/j.wasman.2006.12.022

Stephen, O. A., \& Elijah, I. O. (2011). Healthcare waste management in Nigeria: A case study. Journal of Public Health and Epidemiology, 3(3), 99-110.

Toyobo, A. E., Raba, A. O. \& Oyeniyi, A. B. (2012). Appraisal of University Teaching Hospital Medical Waste Management in Nigeria; Case studies of Universities College Hosptial (UCH) Ibadan and Obafemi Awolowo Universiy Teaching Hosptial (OAUTH) Ile-Ife. Universal Journal Education and General Studies, 1(9), 290-27.

Ujuwal, G. (2009). Health Care Waste Management. Retrieved from ww.slideshare.net/ujuwalgautam/health-care waste management.

Vikas, T., \& Ramesh, A. (2015). Health care waste management research. Waste Management \& Research, 33(10), 855-870.

World Health Organization. (2004). Healthcare waste management. Geneva, Fact sheet No. 281 


\section{Copyrights}

Copyright for this article is retained by the author(s), with first publication rights granted to the journal.

This is an open-access article distributed under the terms and conditions of the Creative Commons Attribution license (http://creativecommons.org/licenses/by/4.0/). 